Karolina Galewska

Instytut Filologii Polskiej, Uniwersytet im. Adama Mickiewicza w Poznaniu

\title{
Chiny wyobrażone - Chiny ucieleśnione. Państwo Środka w polskich i serbskich relacjach z podróży (od XVIII do połowy Xx wieku)
}

Wielość elementów definicyjnych składających się na pojęcie kultury i różnorodność jej teoretycznych ujęć przekłada się na pewną nieuchwytność konstruktu, jakim jest kultura narodowa. Świadomość, że nie da się stworzyć całościowego, wyczerpującego obrazu danego państwa i jego mieszkańców, skłania badaczy do poszukiwań reprezentatywnych składników specyfiki owych wspólnot, pozwalających scharakteryzować je przy wykorzystaniu optyki pars pro toto. Według Anny Wierzbickiej cennych informacji o grupie posługującej się danym językiem może dostarczyć analiza występujących w nim tzw. kluczowych słów, których semantyka jest ściśle związana z doświadczeniem czy obyczajowością narodu [zob. np. Wierzbicka 2020]. W perspektywie literaturoznawczej naprzeciw wspomnianemu dylematowi wychodzi chociażby geopoetyka, proponując interpretowanie kultury przez pryzmat kształtowanej w jej obrębie przestrzeni. Do takiego modelu badawczego nawiązują rozważania Tomasza Ewertowskiego, skoncentrowane wokół kilkunastu chińskich miast, mających stanowić swoiste miejsca-klucze umożliwiające rekonstrukcję wyobrażeń na temat Państwa Środka. 
Wydana w ostatnim kwartale ubiegłego roku książka Images of China in Polish and Serbian Travel Writings (1720-1949) jest świadectwem poszukiwań wyróżników chińskiej kultury na podstawie tropu geograficzno-literackiego. Autor dokonuje syntezy obrazu Chin wyłaniającego się z relacji Polaków i Serbów poświęconych poszczególnym miejscom ${ }^{1}$. Przedmiotu opisu nie stanowi zatem rzeczywistość obiektywna, ale zbiór jej reprezentacji, ukształtowanych z perspektywy Obcego. Zgodnie z założeniami imagologii analizie poddaje się kategorie mentalne, za pomocą których dokonujemy obserwacji otaczającego nas świata, a w szczególności utrwalone w podróżniczych dyskursach etnotypy [Ewertowski 2020: 7]. Kategorie etniczności i narodowości są, według Joepa Leerssena [2017: 10], „obok płci, prawdopodobnie najgłębiej zakorzenionym sposobem przyporządkowania ludzkiego zachowania do określonego zestawu cech". Najnowszy tom z serii Studia Imagologica nie tylko prezentuje ów zestaw cech w odniesieniu do chińskiego społeczeństwa, lecz także bada kontekst ich formowania się i funkcjonowania jako stereotypów [Ewertowski 2020: 7].

Stereotypowe wyobrażenie Chin jest głęboko zakorzenione w świadomości europejskiej. U jego źródeł leżą relacje podróżników z tzw. krajów imperialnych, które pierwsze nawiązały kontakty z Państwem Środka i ukształtowały określony dyskurs w stosunku do mieszkańców terenów zawłaszczanych pod pretekstem idei cywilizowania. Na tym tle pisma Serbów i Polaków stanowią swoisty głos mniejszości, determinowany zupełnie innymi uwarunkowaniami socjopolitycznymi. Z jednej strony przedstawicieli tych nacji łączą przede wszystkim doświadczenia utraty suwerenności i obcego zwierzchnictwa, w związku z czym w kontekście kolonializmu możemy traktować ich jako współdzielących losy Chińczyków. $\mathrm{Z}$ drugiej strony w wielu przypadkach odwiedzali oni dalekowschodnie ośrodki jako obywatele czy wysłannicy mocarstw-agresorów; ich punkt widzenia bywał zatem uwikłany w różnego rodzaju dysonanse [zob. Ewertowski 2020: 4-5]. Pomimo skomplikowania kwestii narodowej autoidentyfikacji, w zetknięciu

1 Przekłady tekstów na język angielski przytaczane są w autorskim tłumaczeniu Tomasza Ewertowskiego [2020: 1]. 
z odległym kulturowo Orientem twórcy analizowanych zapisków odczuwali przede wszystkim przynależność do wspólnoty Starego Kontynentu i patrzyli na świat oczami spadkobierców jej dziedzictwa [Ewertowski 2020: 75]. Autorzy wspomnień, będących przedmiotem monografii, stanowią grupę heterogeniczną narodowościowo, ale jednolitą pod względem nadrzędnych „ram oglądu”. Wszyscy pisali z perspektywy białego Europejczyka i chrześcijanina, co sprawia, że ich relacje odczytujemy dziś przez pryzmat krytyki postkolonialnej [Ewertowski 2020: 13-14, 88].

To właśnie czynniki wpływające na postawę przybyszy z Zachodu i kontekst wyrażanych przez nich sądów (społeczny, polityczny, intelektualny) znajdują się w centrum uwagi Ewertowskiego [2020: 21]. Obserwacje poszczególnych osób są traktowane jako wypadkowa ich życiowego doświadczenia, trybu podróży, momentu historycznego, prądów myślowych epoki i literackiej konwencji [Ewertowski 2020: 358]. Wielorakie konfiguracje powyższych aspektów prowadzą do przyjmowania różnorodnych perspektyw, które w odmienny sposób profilują nawet te same obiekty i przestrzenie. Analiza kilkudziesięciu spersonalizowanych ujęć chińskiej kultury pozwala zarysować amalgamat wyobrażeń obcokrajowców na temat jej materialnych aspektów, wybranych miejsc oraz ogólnego obrazu Państwa Środka. Wyłaniają się one na styku jednostkowej refleksji oraz reprodukcji utrwalonych schematów kognitywnych [zob. Ewertowski 2020: 15]. Z tego powodu korpus tekstów dobrano według kryterium indywidualnego przeżycia, a za klucz gatunkowy przyjęto formułę dziennika podróży (travelogue).

Rozpatrywanie dyskursu pod kątem podmiotowości piszącego powoduje, że kwestia tożsamości staje się jedną z głównych kategorii opisu. Kurs rozważań podróżujących wyznacza przede wszystkim rola, którą przyjmują, odbywając wyprawę na Wschód. Autorzy badanych tekstów prowadzili zapiski jako misjonarze, księża, dyplomaci, dziennikarze, żołnierze, naukowcy, uciekinierzy i wygnańcy ${ }^{2}$ oraz turyści ${ }^{3}$. Role te determinują określone cele i kształtują retoktórzy trafili na Syberię [Ewertowski 2020: 47]. 
rykę formułowanych poglądów. Jest to jeden z aspektów pomniejszających wartość poznawczą poszczególnych relacji. Przykładowo $\mathrm{w}$ pismach duchownych dostrzegamy tendencję do demonizowania przedstawicieli obcej nacji, wynikającą z potrzeby uzasadnienia działalności misyjnej. Podobnym dążeniem obarczona jest postawa przedstawicieli głęboko wpojonego europocentrycznego światopoglądu, niekoniecznie uświadomionego, charakteryzująca większość omawianych przekazów. Skutkuje ona mimowolnym przyjęciem perspektywy kulturowej wyższości i oceniających kryteriów obserwacji. Stosunek ten warunkowało wiele czynników, m.in. wzrost rangi statusu etnicznego Polaków i Serbów na Dalekim Wschodzie. W układzie sił Starego Kontynentu to te narody były podporządkowane ościennym mocarstwom, w Azji zaś ich przedstawiciele stawali się reprezentantami zachodnich imperiów. Niekiedy rekompensowali nawet swój kompleks względem krajów uważanych za twórców potęgi europejskiej, postrzegając się jako współautorów ich sukcesu, np. poprzez udział w budowie Kolei Wschodniochińskiej ${ }^{4}$ [Ewertowski 2020: 70-71; 93].

Udokumentowane przez Polaków i Serbów wyprawy w dużej mierze przypadały na czas europejskiej ekspansji w Chinach i często dotyczyły wizyt w miejscach okupowanych bądź zasiedlanych przez Europejczykóws. Te okoliczności w szczególny sposób wpływały na pozycję podróżujących i ich doświadczanie obcej kultury. Narzucona relacja nadrzędno-podrzędna uniemożliwiała neutralną obserwację i potęgowała odczucie inności. W zeuropeizowanych ośrodkach Chińczycy jawili się bowiem przybyszom jako swego rodzaju „niepasujący element”, zaburzający - w ich mniemaniu - naturalny porządek rzeczy. Wielu z nich było przekonanych o cywilizacyjnej misji Zachodu i cechowało się bezkrytycznym stosunkiem do kolonizatorskich praktyk. Ich nastawienie

Głównie z budową Kolei Wschodniochińskiej związane są doświadczenia podróży na obszary pogranicza rosyjsko-chińskiego, regionu nazywanego wówczas Mandżurią [Ewertowski 2020: 110].

5 Większość relacji dotyczyła terenu północno-wschodnich Chin, pozostającego w rosyjskiej strefie wpływów, a także miast portowych na wschodnim wybrzeżu, do których prawa eksterytorialne posiadały mocarstwa zachodnie [Ewertowski 2020: 359]. 
było silnie zideologizowane, a pisanie podporządkowane przyjętej z góry tezie. $Z$ tego powodu liczne krytyczne uwagi na temat Chińczyków, odnoszące się przede wszystkim do brudu i specyficznego zapachu, skutkujące niekiedy nawet porównaniami do zwierząt [zob. Ewertowski 2020: 289], są prezentowane w monografii jako pochodne określonego punktu widzenia, uformowanego zazwyczaj jeszcze przed kontaktem z chińskimi realiami. Imperialna retoryka prowadziła do zniekształcających interpretacji zastanej rzeczywistości. Wnioski niektórych przyjezdnych sugerowały, że strona chińska korzystała znacznie bardziej z obecności Europejczyków niż zachodnie mocarstwa ze swojej ekspansji i powinna być wdzięczna za narzucone zwierzchnictwo [Ewertowski 2020: 331].

Czas powstawania XIX-wiecznych dzienników podróży przypada na okres, w którym inność była wartościowana negatywnie, a edukacja nie uwzględniała koncepcji relatywizmu kulturowego. W związku z tym autorami tych zapisów kierowała nie tyle zła wola, ile brak przygotowania na otwartość i afirmatywny stosunek do odmienności. Spotkanie z Innym najczęściej naznaczone było niezrozumieniem. Wszystko, co odbiegało od europejskich standardów, odbierane było jako dziwne lub niewłaściwe. Nawet pozytywne wrażenie wywołane widokiem Świątyni Nieba w Pekinie wiązało się u Ignacego Posadzy z nadzieją, iż kiedyś budynek ten stanie się miejscem kultu religii chrześcijańskiej [Ewertowski 2020: 37]. Piszący często nie zdawali sobie sprawy, że mimo chęci nie potrafią wyzbyć się podświadomego przekonania o prymacie własnego zaplecza obyczajowego. Tę grupę reprezentuje m.in. Władysław Zaleski. Misjonarz krytykował narzucanie Chińczykom zachodniego stylu życia, a jednocześnie był zagorzałym zwolennikiem nawracania ich na katolicyzm [Ewertowski 2020: 325]. Tego typu narracja nie stanowiła jedynie pokłosia kształcenia w duchu darwinowskim. Jak zauważa Ryszard Nycz [2015: 8], także osiągnięcia antropologii kulturowej z początków Xx wieku obarczone są postawą dominacji wobec Innego, bowiem

antropolog, występujący tu w roli uczestniczącego obserwatora, specyficzne formy i treści lokalnej kultury przekładał na 
„uniwersalny” słownik opisu, który był de facto słownikiem euro-amerykańskiej antropologii poznania historycznego.

W pismach przybyszy z Zachodu etnocentryzm objawia się w mniej lub bardziej „przyjaznej” postaci [Ewertowski 2020: 353]. Niekiedy inność odbierana jest w kategoriach intrygującej egzotyki, co poświadczają chociażby odwołania do Baśni tysiąca i jednej nocy w opisie odwiedzanych miejsc [Ewertowski 2020: 357]. Posługiwanie się figurą wyśnionej krainy cudów jest jednak również naznaczone protekcjonalną, stygmatyzującą perspektywą, pozbawiającą Chiny realnej podmiotowości [Ewertowski 2020: 358]. Z zachowanych relacji Europejczyków wynika, że najczęściej percypowali oni doświadczenia podróży w głąb Azji przez pryzmat mentalnych matryc uformowanych pod wplywem rozpowszechnionych stereotypów, i nawet konfrontacja z rzeczywistością nie prowadziła do ich reinterpretacji, refleksyjnego przetworzenia. Jak dowodzą analizy Ewertowskiego, większość opisów reprodukowała utrwalone w kulturze zachodniej schematyczne wyobrażenia i konwencje $^{6}$, w związku z czym przedstawienie typowych lejtmotywów występujących w dyskursywnych reprezentacjach Chin stanowi oś konstrukcyjną drugiej części monografii i pozwala autorowi zmienić optykę z lokalnej na globalną [Ewertowski 2020: 85].

Przeobrażenia funkcjonujących stereotypów odsłaniają specyficzną korelację między poznaniem Innego a stosunkiem do niego. Do XIX wieku Chiny były państwem niedostępnym i odizolowanym. Wówczas w Europie rozwijała się fascynacja dalekowschodnią sztuką i wyrobami, z estymą podchodzono do tradycji i filozofii tamtejszego społeczeństwa. Wraz z rozwojem kontaktów między regionami obraz Państwa Środka stawał się coraz bardziej negatywny. Przyczyną było przede wszystkim narzucanie przez osadników na okupowanych przez Europejczyków terenach własnego wzorca kulturowego jako standardu wartościowanego pozytywnie.

6 Niektóre z nich wykształciły się w obrębie dyskursów określonych prądów kulturalno-intelektualnych. Ewertowski [2020: 47] wspomina m.in. o „oświeceniowej wizji Chin jako królestwa pokoju i krainy mądrości [przel. - K.G.]”, a także o herderiańsko-heglowskim wyobrażeniu, w którym Państwo Środka ucieleśnia stagnację i zacofanie. 
Orient stracił rangę magicznej krainy, a jego mieszkańców zaczęto postrzegać w kategoriach zagrożenia i swego rodzaju dewiacji. Idylliczna wizja chińskiej harmonii i wytworności zdezaktualizowała się również ze względu na trudną sytuację wewnętrzną cesarstwa. Problemy społeczne, takie jak przeludnienie, bieda i głód, doprowadziły do upadku dynastii Qing i krwawych powstań [Ewertowski 2020: 67]. Niemniej to interesy imperialnych mocarstw przyczyniły się do wykształcenia się deprecjonującej retoryki w stosunku do Chin. W dostrzeżeniu możliwości utylitarnego wykorzystania azjatyckich dóbr oraz rodzeniu się europejskiej pychy w związku z naukowym, technologicznym i ekonomicznym postępem możemy upatrywać źródła agresji wobec Państwa Środka, a także początków wyższościowego dyskursu w pisarstwie podróżniczym [Ewertowski 2020: 65-67]. O ile w XVII i XVIII stuleciu obcokrajowcy z zaciekawieniem rejestrowali odmienne obyczaje, o tyle w późniejszych relacjach zaczęło przeważać zainteresowanie materialnymi aspektami kultury w perspektywie ich przydatności gospodarczej [Fritzsche 1995; cyt. za: Ewertowski 2020: 67].

Konfrontacja cywilizacji europejskiej i chińskiej doprowadziła do wyostrzenia kontrastów w stereotypowych wyobrażeniach poszczególnych ras. Uwagi na temat Państwa Środka formułowane były najczęściej na zasadzie przeciwstawienia w stosunku do świata zachodniego, przez co utrwalały się dychotomiczne obrazy w rodzaju „nowoczesna, dynamiczna Europa” i „statyczne, tradycjonalistyczne Chiny" [Ewertowski 2020: 359-360]. Empiryczne podstawy tak konstruowanych reprezentacji podważyła w powojennej humanistyce imagologia. Literaturoznawcy dostrzegli,

że opisy narodów odnosiły się przede wszystkim nie do zewnętrznej rzeczywistości antropologicznej, ale do opartej na opozycjach, dyskursywnej ekonomii opisów innych narodów, głównie wzdłuż osi Swój vs. Obcy. [Leerssen 2017: 12]

W kontakcie Europejczyka ze społeczeństwem azjatyckim efekt obcości jest spotęgowany doznaniem braku wspólnych korzeni kulturowych. Doświadczenia podróży po Starym Kontynencie naznaczone są zawsze wrażeniem „powrotu do źródeł”, odkry- 
wania tego, co już jest w jakimś stopniu nam znane ${ }^{7}$ [Ewertowski 2020: 167]. Z kolei wyprawa na Wschód oznacza porzucenie poczucia przynależności. Niewielu autorów analizowanych tekstów miało możliwość obserwacji uczestniczącej, przekroczenia powierzchownej, zewnętrznej perspektywy. Większość z nich nie wchodziła w interakcje z przedstawicielami miejscowych wspólnot, stanowiących swego rodzaju enklawy również ze względu na barierę językowąa. Jak wskazuje Ewertowski [2020: 228], system pisma chińskiego był jednym z głównych czynników wpływających na poczucie wyobcowania przybyszy z Zachodu.

Relacje zebrane w korpusie dotyczą głównie stref granicznych i miejsc zasiedlonych przez obcokrajowców ${ }^{9}$, dlatego ich autorzy mogli odbywać podróż bez rzeczywistej immersji w chińską kulturę. Nawet w wielonarodowościowych miastach poszczególne grupy etniczne rzadko mieszały się ze sobą ${ }^{10}$ [Ewertowski 2020: 95]. Między innymi z tego powodu przybysze z Europy zazwyczaj mieli kontakt ze swoistą imitacją bądź namiastką doświadczenia kulturowego. Występowali w roli uprzywilejowanych przedstawicieli białej rasy [Ewertowski 2020: 54], których traktowano ze stosownym dystansem, a nawet podziwem i czcią, jakie wywołuje w Azji kolor skóry Europejczyka. Ponadto warto zauważyć, że turyści udający się w owych czasach do Chin ${ }^{11}$ pochodzili z warstw społecznych o najwyższym statusie, w związku z czym podróżowali w lektykach, mieszkali w luksusowych apartamentach i nie mieli styczności z realiami życia lokalnych społeczności [Ewertowski 2020: 199]. Mimo to możemy znaleźć relacje postaci, którym udało się prze-

7 Tę prawidłowość Duncan F. Kennedy [1999; cyt. za: Ewertowski 2020: 167] oddaje słowami: „Rome visited is always in some sense Rome revisited”.

8 Tylko niektórzy z autorów omawianych $\mathrm{w}$ monografii tekstów posługiwali się językiem chińskim [Ewertowski 2020: 303].

9 Najbardziej wyrazisty przykład stanowi Harbin, który na początku xx wieku zamieszkiwany był przez przedstawicieli 53 narodowości posługujących się 45 językami [Ewertowski 2020: 111]. Harbińska Polonia tworzyła jedną z największych grup etnicznych, zaraz za dominującymi Chińczykami i Rosjanami [Ewertowski 2020: 114].

10 Przykładowo Konstanty Symonolewicz opisuje przypadek rosyjskiego pracownika kolei, żyjącego w Mandżurii od 20 lat i krytykującego Chińczyków za to, że nie potrafią mówić „w żadnym ludzkim języku” [Ewertowski 2020: 94].

11 Przypomnijmy, że korpus tekstów obejmuje lata 1720-1949. 
kroczyć granice własnego etnocentryzmu i poczynić obserwacje pozbawione uprzedzeń.

Podczas gdy „niektórzy podróżujący okazywali pogardę lub co najmniej brak zainteresowania chińską kulturą, zauważali głównie zaniedbanie i brud, ci o bardziej otwartych umysłach mogli dostrzec dużo więcej [przeł. - K.G.]” [Ewertowski 2020: 130]. Pojawiały się refleksje całkowicie odwracające kolonialną retorykę, wyrażające przekonanie, że Chiny nie zyskały niczego w wyniku kontaktu z Europą, lecz to Europa znacznie wzbogaciła się dzięki uzyskaniu dostępu do dziedzictwa kulturowego Chin [Ewertowski 2020: 325]. Milan Jovanović w niezwykle krytyczny sposób scharakteryzował zachodnią cywilizację, stwierdzając, iż „za wszystkie radości, które oni [Chińczycy - K.G.] wnoszą do naszego życia, my dajemy im tylko dwie rzeczy, które życie niszczą - opium i broń [przeł. - K.G.]” [Jovanović 1895; cyt. za: Ewertowski 2020: 326]. Takie spostrzeżenia stanowiły przeciwwagę wobec propagowanych przez zwolenników euroamerykańskiej dominacji koncepcji „żółtego niebezpieczeństwa”, rzekomo zagrażającego Zachodowi [Ewertowski 2020: 326]. Budowanie dyskursu opartego na opozycyjnych reprezentacjach nie zawsze było narzędziem deprecjonowania obcej nacji. W części stereotypowych ujęć to Państwo Środka stanowiło niedościgniony wzór dla Starego Kontynentu, co poświadczają chociażby porównania pokojowego usposobienia Chińczyków i europejskiej agresji [Ewertowski 2020: 306]. $\mathrm{W}$ podobnym tonie wypowiada się pewien wietnamski mandaryn, będący bohaterem dziennika Władysława Jagniątkowskiego: „Francuzi budują pomniki na cześć Napoleona, z kolei mieszkańcy Dalekiego Wschodu pogardzają żołnierzami; Europejczycy dążą do bogactwa, prędkości i siły, a w Azji preferuje się spokój i umiarkowanie [przeł. - K.G.]” [Ewertowski 2020: 356]. Jest to jeden z przykładów relatywizacji norm obyczajowych reprezentowanych przez Polaków i Serbów.

Zmiany w postrzeganiu Chin udokumentowane w omawianych pismach podróżniczych do pewnego stopnia odzwierciedlały dominujące tendencje i prądy myślowe epoki. Między innymi doświadczenia wielkich wojen wpłynęły na negatywną ocenę europejskiej interwencji w Azji i powrót do przychylniejszego portretowania 
Państwa Środka, co znajdowało wyraz w aurze nostalgii oraz żalu z powodu modernizacji narzuconej tradycyjnej cywilizacji chińskiej [Ewertowski 2020: 10], a nawet idealizowaniu moralności i dyscypliny „mędrców ze Wschodu” wobec kryzysu zachodniego systemu wartości [Ewertowski 2020: 180]. Niemniej uwarunkowania historyczne nie mają prostego przełożenia na postawę autorów tekstów. Propaganda głosząca europejską wyższość kulturową nie przeszkodziła niektórym przybyszom w wyrażaniu zachwytu nad Chinami [Ewertowski 2020: 360]. Trudno także wskazać reguły oddziaływania innych czynników, takich jak narodowość czy pochodzenie społeczne obserwatora [Ewertowski 2020: 362]. Kluczową rolę odgrywa zawsze osobiste doświadczenie, w niepowtarzalny sposób kształtujące kompetencje poznawcze każdego człowieka $^{12}$. To ono stanowi soczewkę, przez którą patrzymy na świat. Z tego powodu Witoldowi Jabłońskiemu, mężowi slawistki, Makau kojarzyło się z Dalmacją [Ewertowski 2020: 158], a Romanowi Fajansowi, pamiętającemu czasy przynależności Polski do Cesarstwa Rosyjskiego, Szanghaj przypominał Warszawę sprzed I wojny światowej [Ewertowski 2020: 127]. Odnoszenie nowych wrażeń, znamionujących spotkanie z obcą kulturą, do odczuć nam bliskich, znanych, określane jest mianem domestykacji i stanowi jedną ze strategii oswajania Innego, szczegółowo analizowanych przez Ewertowskiego [2020: 19].

Indywidualizacja odbioru doświadczania nieznanego jest wyraźnie widoczna również w opisie tych samych miejsc, także gdy powstają w zbliżonym przedziale czasowym. Przykładowo w relacjach dwóch zbiegów z rewolucyjnej Rosji, Kamila Giżyckiego i Jerzego Bandrowskiego, chińskie dzielnice Hong Kongu zostają ukazane w przeciwstawny sposób: „[... ] jeden przypisał tej części miasta cechy europejskie, a drugi określił ją jako brudną

12 Niewątpliwie $\mathrm{w}$ znacznym stopniu jest ono formowane podczas dorastania i życia w określonych warunkach przestrzenno-kulturowych, dlatego zapiski Polaków i Serbów mają różne punkty odniesienia w postaci krajów ojczystych, ich historii, dziedzictwa czy realiów [Ewertowski 2020: 361]. Z tego powodu „na Wielkim Murze Rajčević [Milorad - K.G.] odwołał się do bitwy na Kosowym Polu, a Kowalewski [Józef - K.G.], przekraczając chińsko-mongolską granicę, zacytował polskiego poetę Adama Mickiewicza [przeł. - K.G.]” [Ewertowski 2020: 361 . 
i zaniedbaną [przeł. - K.G.]” [Ewertowski 2020: 149]. Odczucia, związane m.in. ze sztuką, smakami, zapachami czy zachowaniem Chińczyków, wartościowane przez jednych negatywnie, zyskiwały przychylność innych obcokrajowców. Spersonalizowane schematy konceptualizowania rzeczywistości w szczególny sposób odsłaniane są w tekstach o charakterze „stereoskopowym” (stereoscopic form of writing), prezentujących wspomnienia z jednej podróży zapisane przez kilka różnych osób [Ewertowski 2020: 36, 130]. $\mathrm{Z}$ tego powodu konstruowanie obrazu poszczególnych lokalizacji, którym poświęcona jest główna część monografii, sprowadza się do zestawiania wielorakich opinii i wyobrażeń na ich temat. W ten sposób tworzy się raczej migawkowy niż przekrojowy profil topograficzno-kulturowy.

Wydaje się, że pozycja poświęcona przede wszystkim Chinom w pierwszej kolejności stanowi studium o piszących o niej Polakach i Serbach - przybyszach z Europy. Zgodnie z sentencją przypisywaną Anaïs Nin, nie widzimy rzeczy takimi, jakie one są, lecz jakimi my jesteśmy. To sformułowanie doskonale oddaje charakter monografii Ewertowskiego, która na podstawie zapisków dotyczących Państwa Środka zgłębia tożsamości poszczególnych autorów, odkrywając ich motywacje, uprzedzenia, kompleksy oraz ideologie kształtujące indywidualne dyskursy. W wyniku tej analizy wyłania się mozaika ${ }^{13}$ atrybutów i wyobrażeń kształtujących w minionych wiekach na Zachodzie obraz Chin: mężczyźni z warkoczami, tętniące życiem ulice, riksze, pałeczki, brak postępu, konserwatyzm, egzotyka i wiele innych. Zadaniem imagologii jest dekonstruowanie esencjalizmu tego typu „stereotypowych atrybucji charakteru narodowego" [Leerssen 2017: 9]. Powstają one w wyniku akumulowania reprezentacji etnotypów w pojedynczych tekstach utrwalających określone formuly retoryczne [Leerssen 2017: 17]. Wydobycie ich związków oraz ukrytych znaczeń, postulowane przez Leerssena, pozwoliło zrekonstruować Ewertowskiemu rozległą sieć relacji między polskimi i serbskimi pismami podróżniczymi, a co za tym idzie, między ich twórcami, przedstawicielami różnych epok, profesji czy warstw społecznych.

13 Tym określeniem sam autor podsumowuje swoje rozważania - zob. rozdział Final Remarks - the Chinese Mosaic [Ewertowski 2020: 359-363]. 


\section{Bibliografia}

Ewertowski Tomasz (2020), Images of China in Polish and Serbian Travel Writings (1720-1949), Brill Rodopi, Leiden-Boston.

Fritzsche Sybille C. (1995), Narrating China: Western Travelers in the Middle Kingdom after the Opium War, Ann Arbor,

[University Microfilms].

Jovanović Milan (1895), Tamo amo po istoku. Sveska druga, Srpska

književna zadruga, Beograd.

Kennedy Duncan F. (1999), A Sense of Place: Rome, History and Empire

Revisited, w: Roman Presences. Receptions of Rome in European

Culture, 1789-1945, red. Catherine Edwards, Cambridge University

Press, Cambridge, s. 19-34.

Leerssen Joep (2017), Imagologia: o zastosowaniu etniczności do

nadawania światu sensu, przeł. Emilia Kledzik, „Porównania”, t. 21, nr 2, s. 9-30, https://doi.org/10.14746/p.2017.21.13943.

Nycz Ryszard (2015), Inny jak ja. (Trzy i pót glosy do aktualnego

teoretycznie i praktycznie problemu), „Teksty Drugie”, nr 6, s. 7-14.

Wierzbicka Anna (2020), Stowa klucze. Różne języki - różne kultury,

Wydawnictwa Uniwersytetu Warszawskiego, Warszawa.

Karolina Galewska

China Imagined - China Embodied. The Middle Kingdom in Polish and Serbian Travel Reports (from the Eighteenth to Mid-twentieth Century)

The article presents an overview of the issues discussed in Tomasz Ewertowski's monograph Images of China in Polish and Serbian Travel Writings (1720-1949). It reconstructs the discourse that emerges from the journals as their authors report on their journeys to the Middle Kingdom. The article also analyses the conditioning of the presented attitudes in the context of individual experience. Using imagology-based tools, Ewertowski refers to the mental representations of reality recorded in the text in the form of stereotypically formed ethnotypes. Ewertowski creates a mosaic of the way travellers from the West imagined both Chinese cities and the characteristic features of Far Eastern culture, which is often marked by Eurocentrism and an evaluating attitude towards the Other.

Keywords: travel writing; travelogue; China; imagology; ethnotype; stereotype; post-colonial criticism. 
Karolina Galewska - językoznawczyni, lektorka języka polskiego jako obcego, doktorantka w Szkole Doktorskiej UAM, związana z Pracownią Leksykologii i Logopedii w Instytucie Filologii Polskiej. Zajmuje się przede wszystkim onomastyką, zwłaszcza w perspektywie porównawczej. Bada nazwy polskie, angielskie i chińskie, poświęcając uwagę m.in. zagadnieniom przekładu pomiędzy językami z kręgu kultury europejskiej oraz dalekowschodniej. 
